$\S=$

\title{
Logistics Commitment: An Evidence of Long-term Relationship on Sustainable Global Supply Chain
}

\author{
Sidah Idris $^{1 *}$, Suhana Mohezar ${ }^{2}$ \\ ${ }^{1}$ Senior Lecturer, International Business Program, Universiti Malaysia Sabah. \\ ${ }^{2}$ Senior Lecturer, Operations and Management Information System, University of Malaya \\ *Corresponding author E-mail: syaidah@ums.edu.my
}

\begin{abstract}
Manufactures and all network partners may think that global supply chains are simple and direct. But, in the vast majority of cases, this is not the case. Customer demand is supported by complex and lengthy global supply chain. The intermodal transportations provide the key success of the connections between global factories and along the supply chain parties. While they provide critical services, each level of transportation will present challenge and difficulty to all parties. This study look on how logistics commitment can improves operating efficiencies among local manufacturers and service providers as they are in global supply chain network. And, how each intermodal invested improve capabilities, creating reliable and economical port-to-destination delivery services in ensure good relationship with their partners. The study aims is to identify how the service providers can reshape relationship and revise networks to maintain smooth and efficient global logistics flows. This empirical study will use survey questionnaire to get the answer for each question and utilize Partial Least Square (PLS) to analyse the data. Result shows how logistics commitment effort and strategy as to sustain global supply chain relationship.
\end{abstract}

Keywords: Logistic Commitments, Global Supply Chain, Relationship, Strategies, Sustainability.

\section{Introduction}

The supply chain encompasses all activities associated with the flow and transformation of goods from raw materials stage (extraction), through to the end user, as well as the associated information flows. Material and information flow both up and down the supply chain. Supply chain management (SCM) is the integration of these activities through improved supply chain relationships to achieve a sustainable competitive advantage.

The aims of this study in general is to identify how logistics commitment can sustain business relationships among global supply chain partners by reshape relationship and revise networks to maintain smooth and cost-efficient global logistics flows. Specifically, this study are to understand what factors that influence logistics commitment in global supply chain relationship; to test what factors significantly influence global supply chain relationship; and to identify in what degree the role of service provider will moderate the relationship of logistics commitment between trust, coordination, top management support, shared value, and financial commitment with global supply chain in the long-term relationship.

\section{Global Supply Chain}

Globalized market environments now offer significant opportunities for multinational companies to move their manufacturing and distribution activities throughout the world especially among developing and emerging markets. Despite the opportunities provided with the reduced trade barriers, the domestic manufacturing firms may face dangers of being excluded from the global supply chain owing to their limited capability in complying with greater quality standards, offering competitive prices, absorbing new technology and producing innovative products. Even within this context researchers argue that the global manufacturing strategies alone may not be effective if not supported by successful logistics and effective supply chain management strategies (1) and more attention to sustainability of this sector (2).

The movement of goods internationally is a huge business with trillions of dollar worth of products moving around the world. The global journey always involves multiple carriers from different modes, numerous border crossings, and long distances. The risk of disruptions, delays, damage, low productivity and other problems make for an eventful time whether the company are importing electronics or exporting fresh products. According to Institute for Sustainability as cited in (3) has defined business sustainability as "the increase in productivity and/or reduction of consumed resources without compromising product or service quality, competitiveness, or profitability while helping to save the environment."

\section{Long Term Relationship and Global Supply Chain}

Relationship refers to the willingness of one party to commit and maintain a relationship through various factors and as a measure of strength and success of an inter-organizational relationship (4) and represents the peak through long-term relationship (5). Term of commitment has typically been defined as a channel member's intention to continue the relationship (6). The concept of commitment is similar to the concept of a long-term orientation that re- 
flects the desire and utility of a buyer to have a long-term relationship with a seller (7). Morgan and Hunt (8) also suggested that the propensity for relational continuity and the establishment of longterm relationship are central system of belief of relationship commitment (9).

Committed service providers who are engaged in all or part of the firm's product distribution function, allow the shipper to focus on its core competencies rather than on the distribution expertise. Thus collaboration between service providers is essential for successful outcome for the organization. Coordination (10) is very important enabler of the relationship to move towards the shared goal (11). In Ellram's (12) study, partnership success factors identified shared goals as a high-ranking factor. Other studies (11-14) confirm the importance of shared goals. And, participation (10) and time spent together also factors enables service provider to understand capabilities of each other (15).

Since global supply chains can reflect as much as $90 \%$ of a company's cost base (16), complete knowledge and understanding of these logistic relationship costs are critical for effective business management and company performance. The critical nature of business in the future demands that logistics management continuously improve technology, infrastructure, and operations in the global supply chain (GSC). Long-term relationship between service providers creates an atmosphere of trust and commitment which creates tendency to deliver and support GSC. Bradley (17), long-term logistics relationship can provide required transition time to improve the strategic business performance in supply chain.

\section{Logistics Management}

Originally, logistics management in the organisation was only a support function and was sometimes referred as a traffic council within organisation $(18,19)$. However, it now receives increasing attention in corporate strategic planning because of the globalisation of competition and the complexities that have developed. Logistics management has become a key factor in measuring a company's success (20). One of its functions is to create a faultless system that allows a product to be delivered to market efficiently and at minimum cost.

Competition among logistics management providers also adds to the value-added dimension and inspires them to tailor their services needs. When all parties involved in logistics management in providing services to their clients improved, all parties benefit through more cost-efficient, innovative methods, and the capabilities of all strategic allies are expanded along the global supply chain (19). In this case, to ensure that the best services are provided, logistics companies have established strategic alliances with multiple service providers.

The logistics strategic alliances should be initiated. The relationship requires the establishment of a shared, long-term visionary and financial commitment. Top management should provide support for the strategic alliance and should permit the service provider to participate in its logistics management strategic planning. The alliance should have clear, specific and measurable goals in increasing efficiency and reduced delivery frequency.

\section{Global Freight and Intermodal Transporta- tion}

The global freight market will continue to evolve for all modes of transportation. Intermodal transportation involves the use of two or more modes of transportation in moving a shipment from origin to destination. International transportation arrangements from one country to other countries more towards intermodal transportation with involve multiple modes and carriers. The capacity and efficiency of ocean transportation allows large-volume shipments to be transported between continents at relatively low per unit costs.

\section{Methodology}

A quantitative research method utilising a survey questionnaire was employed to examine hypotheses identified in the conceptual framework. The independent variables were measured using 24 items grouped into five constructs - trust, coordination, top management support, shared value. The dependent variables were measured using 10 items to assess a firm's global supply chain relationship. The unit of analysis used in this research is organization and service provider organisations. The questionnaire was forwarded to the key person in the organisation. The key person was identified and selected based on their roles, which make them knowledgeable regarding the issues studied. Hence, this study targeted a person within a firm who is actively involved in the decision-making process relating to the international operations.

A self-administered questionnaire approach was employed as the numbers of sampling frame were considered high and they were located at various locations in Peninsular Malaysia. The statistical analysis method is focusing on estimating a set of model parameters, this study relied on variance-based SEM, using partial least square (PLS)

\section{Theory Applied}

This study aims to explore relationship management theory in logistics commitment management towards global supply chain strategic performance on cost efficient as moderated by service provider role. Relationship management theory was developed early in the marketing field. Several important relationship marketing studies have provided theoretical foundations for effective inter-firm relationship management $(7,21)$.

\section{Framework and Hypotheses}

Previous studies showed how trust and relationship commitment have been identified as critical factors for successful logistics service provider or Third Party Logistics (3PLs) alliance and transactional relationships $(22,23)$. These study hypotheses are:

H1. Trust positively related to GSC relationship.

H2. Coordination positively related to GSC relationship.

H3. Top management support positively related to GSC relationship.

H4. Shared value positively related to GSC relationship.

H5. Financial commitment positively related to GSC relationship.

H6. Service provider positively related to GSC relationship

H7a. Service provider role moderate the relationship between trust and GSC relationship.

H7b. Service provider role moderate the relationship between coordination and GSC relationship.

H7c. Service provider role moderate the relationship between top management support and GSC relationship.

H7d. Service provider role moderate the relationship between shared value and GSC relationship.

H7e. Service provider role moderate the relationship between financial commitment and GSC relationship. 


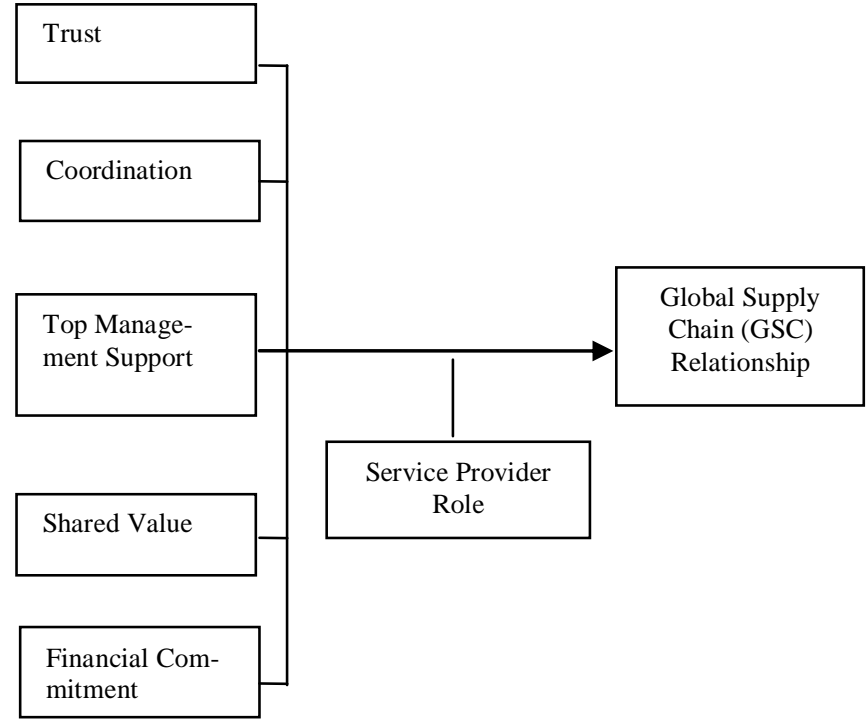

Fig. 1. Logistics Commitment and GSC Relationship.

\section{Results and Discussion}

This study adopted PLS analysis as the primary analytic procedure, which is robust to the violation of non-normality data distribution. The bootstrapping method employed, which allow the researcher to create sub samples from the original data set, enables precise statistical results for non-normally distributed data with a sample size ranging from 50 to 400 (24-26). The results indicate that majority of the responding firms from 78 companies are involve international operations and international logistics arrangement. Almost half of the responding firms have operated within 510 years, with majority of them employed less than 100 employees.

\section{Descriptive and Measurement Model}

Upon completed the missing value analyses, skewness and kurtosis tests were performed to examine the data distribution. Consistent with (25-28), this study used a value of between -2.0 and +2.0 as a cut-off point to represent a normally distributed data. All items had skewness value of below \pm 1.0 . Therefore, they were considered non-extreme, and illustrating that non-normality was not a significant issue.

The mean and standard deviations of all items, as well as Cronbach's alpha of each construct were measured using a 7-point Likert scale. All constructs had Cronbach's alpha values (Table 1) of above the cut-off point 0.70 , indicating that these scales are reliable (29) as cited from Nunnally (30).

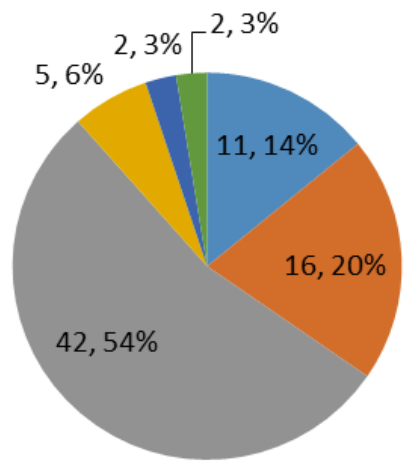

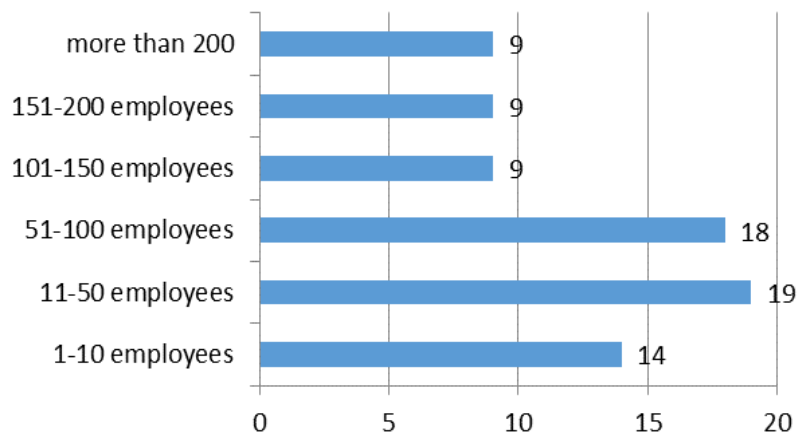

Fig. 3. Number of Employees

Table 1: AVE and Composite Reliability Value

\begin{tabular}{|c|c|c|c|}
\hline Constructs & $\begin{array}{c}\text { No. of } \\
\text { items }\end{array}$ & $\begin{array}{c}\text { Average Variance } \\
\text { Extracted (AVE) }\end{array}$ & $\begin{array}{c}\text { Composite } \\
\text { Reliability }\end{array}$ \\
\hline Trust & 5 & 0.691 & 0.752 \\
\hline Coordination & 5 & 0.769 & 0.714 \\
\hline Top management support & 4 & 0.751 & 0.822 \\
\hline Shared value & 4 & 0.752 & 0.793 \\
\hline Financial commitment & 6 & 0.730 & 0.763 \\
Service provider role & 4 & 0.721 & 0.755 \\
\hline $\begin{array}{c}\text { Global supply chain rela- } \\
\text { tionship }\end{array}$ & 10 & 0.732 & 0.761 \\
\hline
\end{tabular}

\section{Structural Model}

The structural model refers to the relationships between the constructs and is assessed by examining the predictive and explanatory power of the study. The predictive power of a PLS model is evaluated by examining the extent of variance explained (i.e $\mathrm{R}^{2}$ ) in the dependent constructs. Figure 4 shows the structural model results omitting the influence of the interacting moderator variable. Figure 4 also illustrated the $\mathrm{R}^{2}$ value for the GSC relationship. The direct model explains 46.5 percent of the variance in GSC cost efficient.

As refer to Figure 4, all beta path coefficients are positive and statistically significant (at $p<0.05, p<0.01$, and $p<0.001)$. In Figure 5 , with moderating effect also shows all path coefficients are positive and statistically significant. As a basis of comparison, it can be interpreted through direct model and by including the effects of the interacting variables. The direct model explains 46.5 percent of the variance in GSC relationship. In contract, by including the effects of the interacting variables, a bigger proportion of the respective variances in GSC relationship ( $\left.\mathrm{R}^{2}: 0.498\right)$ is accounted for.

Figure 5 shows the result of the structural model with interaction effects. It presents the results of the structural model with moderator variable. As proposed by Chin et al.(31), the hierarchical process to construct and compare models with and without the respective interacting constructs. By including the moderating variable, a higher percentage of the respective variances in GSC relationship $\left(\mathrm{R}^{2}=0.498\right)$ is showed. The explanatory power of the model is examined by testing how well the observed data fit the hypothesised relationship among constructs. This is by examining the sign and statistical significance of the path coefficients of constructs in the PLS model.

Fig. 2. Year of Operations 


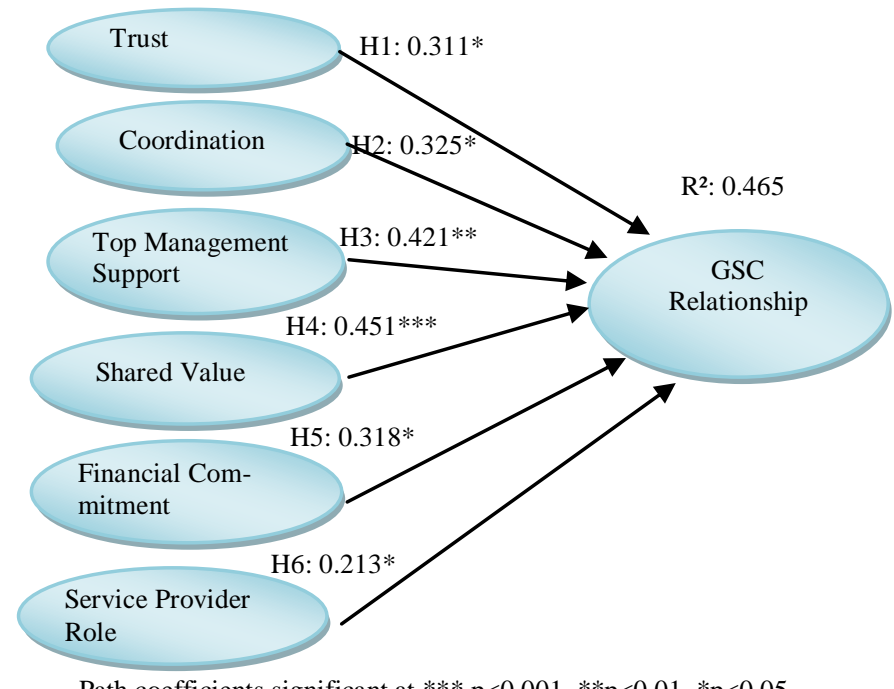

Path coefficients significant at $* * * \mathrm{p}<0.001, * * \mathrm{p}<0.01,{ }^{*} \mathrm{p}<0.05$

Fig. 4. Structural Model Results without Moderating Effects

Table 2: Results of Path coefficient, $\mathrm{T}$-value and $\mathrm{R}^{2}$

\begin{tabular}{|c|c|c|c|}
\hline \multicolumn{2}{|r|}{ Research hypotheses } & \multirow{2}{*}{$\begin{array}{c}\text { Beta } \\
\mathrm{R}^{2}=0.465\end{array}$} & \multirow[t]{2}{*}{ T-value } \\
\hline & & & \\
\hline $\mathrm{H} 1$ & Trust positively related to GSC & 0.311 & $3.478 * *$ \\
\hline $\mathrm{H} 2$ & $\begin{array}{c}\text { relationship } \\
\text { Coordination positively related } \\
\text { to GSC relationship }\end{array}$ & 0.325 & $3.322 * *$ \\
\hline $\mathrm{H} 3$ & $\begin{array}{l}\text { Top management support posi- } \\
\text { tively related to GSC relation- } \\
\text { ship }\end{array}$ & 0.421 & $3.755^{* * *}$ \\
\hline $\mathrm{H} 4$ & $\begin{array}{l}\text { Shared value positively related } \\
\text { to GSC relationship. }\end{array}$ & 0.451 & $3.569 * * *$ \\
\hline H5 & Financial commitment positively & 0.332 & $2.988 * *$ \\
\hline H6 & $\begin{array}{l}\text { related to GSC relationship } \\
\text { Service provider role positively } \\
\text { related to GSC cost efficient. }\end{array}$ & 0.213 & $2.666^{* *}$ \\
\hline & & $\mathrm{R}^{2}=0.498$ & \\
\hline $\begin{array}{l}\mathrm{H}_{\mathrm{a}} \\
\mathrm{H} 7_{\mathrm{b}}\end{array}$ & $\begin{array}{l}\text { Service provider role moderate } \\
\text { the relationship between trust } \\
\text { and GSC relationship Service } \\
\text { provider role moderate the rela- } \\
\text { tionship between coordination } \\
\text { and GSC relationship }\end{array}$ & $\begin{array}{l}0.177 \\
0.143\end{array}$ & $\begin{array}{l}1.042 * \\
1.031 *\end{array}$ \\
\hline $\mathrm{H} 7_{\mathrm{c}}$ & $\begin{array}{l}\text { Service provider role moderate } \\
\text { the relationship between top } \\
\text { management support and GSC } \\
\text { relationship }\end{array}$ & 0.125 & $1.014 *$ \\
\hline $\mathrm{H} 7_{\mathrm{d}}$ & $\begin{array}{l}\text { Service provider role moderate } \\
\text { the relationship between shared } \\
\text { value and GSC relationship }\end{array}$ & 0.142 & $1.022 *$ \\
\hline $\mathrm{H} 7 \mathrm{e}$ & $\begin{array}{l}\text { Service provider role moderate } \\
\text { the relationship between finan- } \\
\text { cial commitment and GSC rela- } \\
\text { tionship }\end{array}$ & 0.159 & $1.333^{*}$ \\
\hline
\end{tabular}

Path coefficients significant at $* * * p<0.001, * * p<0.01,{ }^{*} \mathrm{p}<0.05$

Fig. 5. (See Appendix-A)

\section{Discussion}

This study was carried out to obtain a better understanding the effects of logistics commitment dimension namely trust, coordination, top management support, shared value, and financial commitment in GSC relationship. Based on the descriptive statistics, results showed the respondents are among companies operated more than 11 years. The companies are established and have their own strength in the logistics industry. The hypothesis one is supported and all five hypothesis (H1 to H5) showed logistics commitment dimension positively related to GSC relationship. This finding is consistent with previous research "...developing and maintaining successful relational exchanges, concentrating on committed, interactive and profitable exchanges with selected customers or partners over time (32) emphasises the central roles of trust and commitment in building the social and structural bonds that constitute stable and long-term partnerships (33)". The H6 proposed a positive relationship between service providers and GSC relationship also supported. The result supported by previous study by Song et al.(19), stated that critical nature of business in the future demands that logistics management continuously improve technology, infrastructure, and operations in the global supply chain.

Based on the results of the moderating effect, it showed that trust, coordination, top management support, shared value, and financial commitment in logistics commitment in relation to GSC cost efficient had a positive interacting effect. Thus, $\mathrm{H} 7_{\mathrm{a}}$ to $\mathrm{H} 7 \mathrm{e}$ are accepted. According to Thomas et al.(3), even a small interaction effect can be meaningful under extreme moderating conditions, if the resulting beta changes are meaningful, then it is important to take these conditions into account. It showed that service providers play main role in the relationship between logistics commitment and GSC cost efficient in order to ensure long-term relationship.

\section{Conclusion}

This study highlighted the importance of logistics commitments on GSC in ensure sustainability and long-term relationship among partners. Results from this study may impart to all parties involved in chain network for global supply chain including service providers. Managers should implementing strategies to improve their business performance. In conclusion, this study has important implications for research in global supply chain. It has contributes to the limited research in global supply chain in developing economy, particularly, Malaysia. This study specifically contributes to the logistics management and commitment among players in the industry.

\section{Acknowledgement:}

Thank you to Malaysian Higher Education Ministry (MOHE) and UMS for granted this study (FRG0298-SS-1/2011).

\section{References}

[1] Christopher, M., Khan, O. \& Yun, O. (2011), "Approaches to managing global sourcing risk", Supply Chain Management: An International Journal, 16(2), 67-81.

[2] Alireza Shokri, David Oglethorpe \& Farhad Nabhani, (2014). "Evaluating sustainability in the UK fast food supply chain Review of dimensions, awareness and practice ", Journal of Manufacturing Technology Management, 25 (8), 122 - 124.

[3] Thomas, A., Francis, M., Elwyn, J. and Davies, A. (2011). Identifying the characteristics for achieving sustainable manufacturing companies. Journal of Manufacturing Technology Management, 23(4), 426-440.

[4] Mavondo, F.T. \& Rodrigo, E.M. (2001). The effect of relationship dimensions on interpersonal and interorganizational commitment in organizations conducting business between Australia and China. Journal of Business Research, 52(2), 111-121.

[5] Dwyer, F.R., Schurr, P.H. \& Oh, S. (1987). Developing buyerseller relationships. Journal of Marketing, 51(2), 11-27.

[6] Anderson, E., \& Weitz, B. (1989). Determinants of continuity in conventional industrial channel dyads. Marketing science, 8(4), 310-323.

[7] Gruen, T. W. (1995). The outcome set of relationship marketing in consumer markets. International Business Review, 4(4), 447-469.

[8] Morgan, R.M. \& Hunt, S.D. (1994). The commitment-trust theory of relationship marketing. Journal of Marketing, 58(3), 20-38.

[9] Tian, Y., Lai, F., \& Daniel, F. (2008). An examination of the nature of trust in logistics outsourcing relationship: empirical evidence from China. Industrial Management \& Data Systems, 108(3), 346367.

[10] Mohr, J., \& Spekman, R. (1994). Characteristics of partnership success: partnership attributes, communication behavior, and conflict 
resolution techniques. Strategic management journal, 15(2), 135152.

[11] Ellram, L. M. (1991). Supply-chain management: the industrial organisation perspective. International Journal of Physical Distribution \& Logistics Management, 21(1), 13-22.

[12] Ellram, L. M. (1995). Total cost of ownership: an analysis approach for purchasing. International Journal of Physical Distribution \& Logistics Management, 25(8), 4-23.

[13] Moody, P. E. (1993). Breakthrough partnering: Creating a collective enterprise advantage. Omneo, Essex Junction.

[14] Qureshi, M. N., Kumar, D., \& Kumar, P. (2007). Modeling the logistics outsourcing relationship variables to enhance shippers' productivity and competitiveness in logistical supply chain. International Journal of Productivity and Performance Management, 56(8), 689-714.

[15] Bullington, K. E., \& Bullington, S. F. (2005). Stronger supply chain relationships: learning from research on strong families. Supply Chain Management: An International Journal, 10(3), 192-197.

[16] Institute of Management Accountants (2008), Cost Management Update, IMA, Montvale, NJ

[17] Bradley, P. (1994). Contract logistics: it's all about costs. Purchasing, 117(6), 56A3-A14.Brown, J.R., Lusch, R.F. \& Nicholson, C.Y. (1995). Power and relationship commitment: their impact on marketing channel member performance. Journal of Retailing, 71(4), 363-392

[18] Pagonis, W. G., Gruikshank, J., \& Cruikshank, J. L. (1992). Moving Moutons: Lessons in Leadership and Logistics from the Gulf War. Massachusetts: Harvard Business School Press.

[19] Song, Y. Y, Maher, T.E., Nicholson, J.D., \& Gurney, N.P. (2000). Strategic alliances in logistics outsourcing. Asia Pacific Journal of Marketing and Logistics, 12(4), 3-21.

[20] Wood, D., Barone, A. \& Murphy, P. 1995. International Logistics. Chapman \& Hall, International Thomson Publishing.

[21] Andaleeb, S.S. (1996). An experimental investigation of satisfaction and commitment in marketing channels: the role of trust and dependence. Journal of Retailing, Vol. 72 No. 1, pp. 77-93.

[22] Morgan, R.M. \& Hunt, S.D. (1994). The commitment-trust theory of relationship marketing. Journal of Marketing, 58(3), 20-38.
[23] Moore, K. R. \& Cunningham, W. A. (1999). Social exchange behaviour in logistics relationships; A shipper perspective. International Journal of Physical Distribution \& Logistics Management, 29(2), 103-121.

[24] Byrne, P. J., \& Heavey, C. (2001). The impact of information sharing and forecasting in capacitated industrial supply chains: A case study.International Journal of Production Economics, 103(1), 420437.

[25] Chou, S. Y., \& Chang, Y. H. (2008). A decision support system for supplier selection based on a strategy-aligned fuzzy SMART approach. Expert systems with applications, 34(4), 2241-2253

[26] Irum, S., Qureshi, M.I., Ashfaq, M., Sami, A., Bhatti, M.N., Umar, A. (2018). A Review of Green Supply Chain Management Practices in Asian Countries. International Journal of engineering and Technology, 7(2.29), 1094-1096

[27] Schumacker, R. E., \& Lomax, R. G. (2004). A beginner's guide to structural equation modeling. Psychology Press.

[28] Hu, L. T., Bentler, P. M., \& Kano, Y. (1992). Can test statistics in covariance structure analysis be trusted?. Psychological bulletin, 112(2), 351.

[29] Yesavage, J. A., Brink, T. L., Rose, T. L., Lum, O., Huang, V., Adey, M., \& Leirer, V. O. (1983). Development and validation of a geriatric depression screening scale: a preliminary report. Journal of psychiatric research, 17(1), 37-49.

[30] Nunnally, J. (1978). Psychometric methods. New York, McGraw Hill.

[31] Chin, W.W., Marcolin, B.L., and Newsted, P.R. (1996). A partial least squares latent variable modeling approach for measuring interaction effects: results from a Monte Carlo simulation study and an electronic-mail emotion/adoption study. Information System Research, 21-41.

[32] Harker, M. J. (1999). Relationship marketing defined? An examination of current relationship marketing definitions. Marketing Intelligence \& Planning, 17(1), 13-20.

[33] Rao, S., \& Perry, C. (2002). Thinking about relationship marketing: where are we now? Journal of Business \& Industrial Marketing, 17(7), 598-614.

\section{Appendix - A}

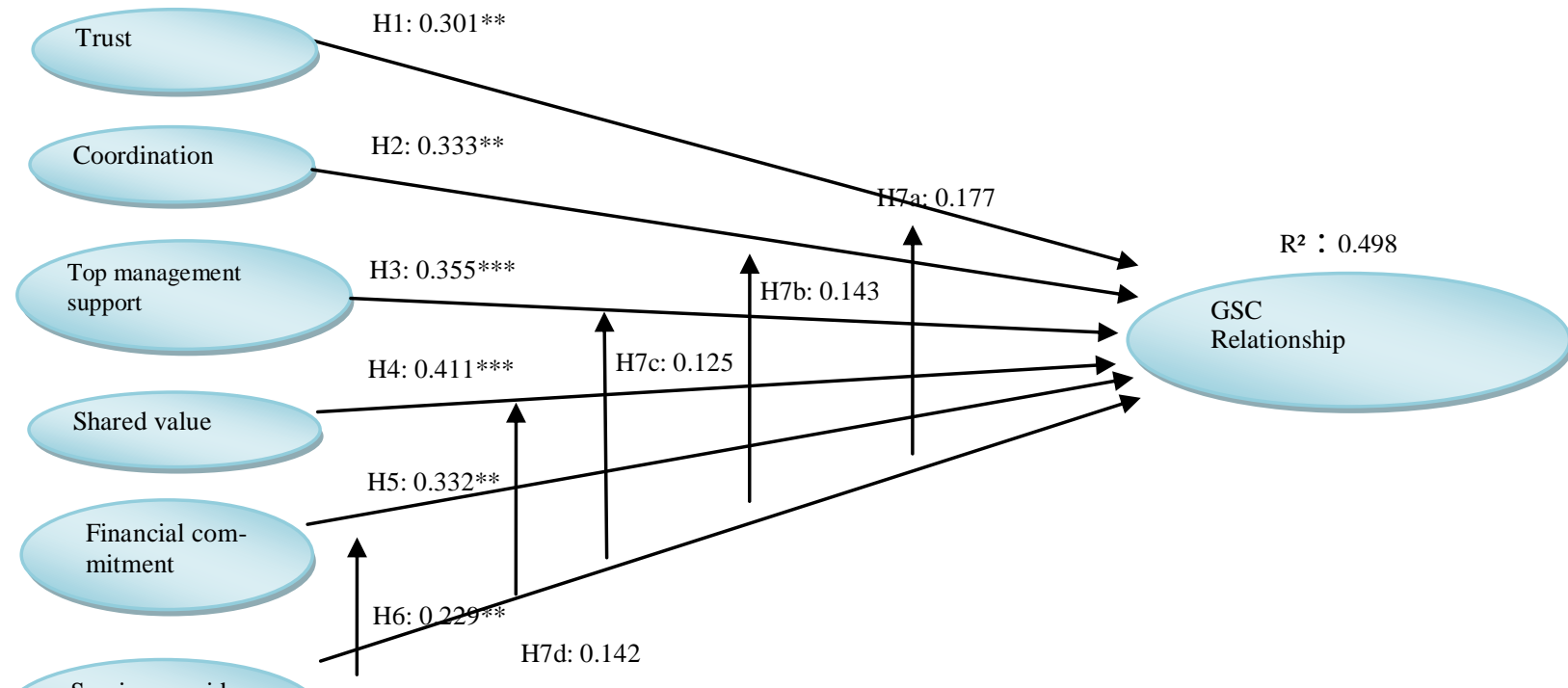

Service provide role
Path coefficients significant at $* * * \mathrm{p}<0.001, * * \mathrm{p}<0.01,{ }^{*} \mathrm{p}<0.05$

Fig. 5. Structural Model Results with Moderating Effects 